\title{
Efficiency of Free Trade Areas and Regional Trade Agreements as Mechanisms of Overcoming Financial Crisis
}

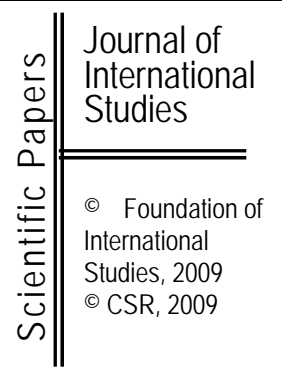

\author{
Pavel Yamko \\ Ukrainian State University of Finance and \\ International Trade \\ yuriyyy@rambler.mu
}

\begin{abstract}
The paper presents organizational-legislative mechanisms of creation and functioning of free trade areas and regional trade agreements as possible facilities of overcoming of financial crisis. Basic directions are certained in relation to collaboration and problems on a way to economic integration within the framework of these agreements. The approaches are offered in relation to the decision of problem questions which arise up in the conditions of global challenges and crisis phenomena in a world economy.
\end{abstract} Submitted: March, 2009 $1^{\text {st }}$ revision: May, 2009 Accepted: June, 2009

Keywords: free trade areas, regional trade agreements, integration, regionalization, WTO.

JEL classification: O24, F43, P1

\section{Introduction}

At the present moment, taking into account a world financial crisis and it gradual deepening becomes clear that it has general system character and to the separate countries it will be hard to overcome it and to manage with its consequences. Only powerful countries and regional associations have possibility of minimization of it negative consequences.

Regional economic integration occurs when countries come together to form free trade areas and regional trade agreements or customs unions, offering members preferential trade access to each others' markets. Advantages of these unions include benefits from the increase of volumes of trade, trade diversion, also gains from diminishing of charges on organization of trade, increased scale and competition. 'Deeper' level of integration can be pursued by going beyond abolition of customs tariffs, import and export quotas. To further measures it is possible to take removement of market segmentation and more complete integration of economies of countries of region.

Effects of free trade areas and regional trade agreements on the world trading system are not clear-cut. Opinions of specialists differ, from one side, FTAs/RTAs detain liberalization of trade relations, and from other, expansion of free trade areas and regional agreements, that proceeds, liberalizes trade of certain regions of the world, and consequently, in the subsequent process of globalization it will be necessary far less efforts for liberalization.

As mechanisms of agreements of World trade organization appeared imperfect and in many cases insufficient, it resulted in the numeral agreements of FTAs/RTAs, which change 
configuration of the already globalizing world substantially. Success of European Union and NAFTA resulted in growth of the amount of the proper agreements. Presently on each of continents there are powerful integration unions which are created on the basis of FTAs/RTAs.

Consequently, as one of possible variants of overcoming of financial crisis is the movement toward regional economic integration, for the sake of proceeding in economies, economic growth and prosperity through the collective and individual actions of membercountries, developed on the basis of program-target method, taking into account the world tendency of passing to the managed economy with the proper growth of role of the states and necessity of balanced protectionism with a necessity and benefits of integration.

\section{The present state}

The last years are characterized by the increase of amount of agreements about FTAs/RTAs. By the state on February, 2009 to GATT/WTO about 400 trade agreements were noted.

It should be noted that the amount of these agreements grows constantly. Thus swinging majority of such agreements are free trade areas. Main reason of it is that free trade areas need less co-ordination of external economic policy, keep independence of countries in forming of customs policy in relation to the third countries, enable to divorce the question of membership within the limits of customs unions, common markets, economic unions and development of simple forms of international integration, also they are more flexible and more dynamic.

The basic requirements and organizational principles of WTO on creation of FTAs/RTAs are contained in the article XXIV of GATT and article V of GATS. In obedience to which the following takes place:

1. WTO allows creation of such areas as an exception from the rules of origin (next to creation of customs unions, conduction of boundary trade, preferential trade for the less developed countries). In these cases countries-participants have more favorable terms for development of mutual trade comparatively with terms for the third countries;

2. The members of WTO must make agreements on FTAs/RTAs only with other member-countries, while with nonmember-countries - only as an exception, although in practice this requirement is executed ambiguously;

3. Passing to free trade must stimulate trade between the proper countries and not create additional barriers to the third countries. Regional agreements must complement principles of forming of the multilateral trade system within the limits of WTO and not be matched against it;

4. The free trading in commodities must be mutual and engulf the basic particle of commodity turnover between parties, inclusive with the basic sectors of economic activity. That touches trading in services: it must engulf quite a bit sectors, eliminate none of methods of supplying with services;

5. A transition to FTA must take a place within 10 years. It is considered that it is a sufficient term, that swinging majority of national producers adapted oneself to the new terms of competition.

Aims of FTAs/RTAs, which member-countries make a decision in accordance with, are set by intergovernmental agreements and, in same queue, are the key organizing principle and motive force for these unions.

Integration processes within the framework of FTAs/RTAs not only support steady economic development of economies of member-countries but also do much in economic integration of certain regions of the world which creates additional competitive advantages for 
them.

This process strikes and constantly supports the economy growing, got in a large measure from trade and investments from other parts of the world. It in same queue testifies that greater non-discriminatory trade liberalization within the framework of multilateral trade connections will be the main force to regional economy growing and integration.

Future of economic integration in the East-European region is enough perspective due to open markets and growing living standards. Basic integration processes will be organic, as businesses and users constantly react on modern tendencies as, for example, development of technologies, and certain demographic tendencies.

Within the framework of these processes the economy of Ukraine can play a leading role in forming and development of economic integration in the East-European region.

However, political instability of Ukraine creates additional barriers on the way to integration, that, in same queue, results in more slow growth and do a region as unit, less competitive globally, when challenges before the economies of region are very much serious.

Among them there is accordance to the global economic requirements. Economies in a region would have to deal with the row of demographic and structural changes, there are not solved problems of energy supply and infrastructure, and also there are ecological problems.

All of these challenges can be solved without reduction of future growth and minimization of certain risks by co-operation between the members of region. Creation of political agreements will help the protracted regional economic development, and also will support integrational processes.

Consequently, there is necessity to create a vast executable program, for the sake of promotion of regional economic integration. Economies of countries of the East-European region have long history of joint activity which enables to move forward economic reform. Trade, constantly growing investment liberalization, free access to the markets can become numberless advantages for a region.

For the sake of creation of these advantages it is necessary to be concentrated on the policy of structural reforms and integration. Only the unions of countries will be able to provide the necessary capacity of markets and facilities which are needed for the sake of strengthening of factors which will support local markets and promote their global competitiveness.

\section{Diagnosis of the problems}

Successful support of economic integration by the agreements of FTAs/RTAs requires the presence of the high-quality and comprehensive legal and economic base, for the sake of trade and investment liberalization and achievement of aims of member-countries of these agreements.

At the same time, there is a problem of unnecessary complexity in commercial treaties, and also presence of certain disagreements among them. For the sake of it there is a necessity to develop the unique document which will contain the system of methodical recommendations on the basis of which it will be possible to create high-quality FTAs/RTAs agreements.

The increase of amount of these methodical recommendations will strengthen the ability of governments of member-countries to create high-quality agreements. In addition, efficiency of methodical recommendations can be increased through the use of program-target method for the sake of their more clear intelligibility and transparency.

Preferential terms of trade are another from of possible areas of future work on the improvement of agreements of FTAs/RTAs. Differences between these terms and complications in their use often are an obstacle for business. Research of different preferential 
terms of trade which are used in a region, their systematization and standardization will create possibility for development of the unique terms and rules and their rationalization.

On a way to economic integration countries of region will appear before certain challenges among which:

terms of trades and investment climate, that change constantly;

necessity of creation of the proper basic principles according to purpose of regional economic integration;

supporting business activity through trade and investment agenda;

support of structural reforms;

strengthening of financial markets;

private sector engagement;

use of program-target method of management.

In the modern world the character of trade and investment policy changes very quickly. These processes find it's reflection in the policy of our region. At the same time the international trade system remains the basis for establishment of economic relations between different countries.

However, at the same time, the economies of some countries use the agreements of FTAs/RTAs more widely, creating yet more favorable terms for liberalization and economy growing. More complex and more effective chains of supply and production appear in reply to the decline of barriers and regional economic integration.

New challenges appear before national economies. The services sector has become the largest component of many regional economies, and business is increasingly concerned about the efficiency, availability and security of economic infrastructure and supply chains. Developments in information and communications technology, changing demographics, and increasing prosperity are increasingly bringing communities together through, inter alia, expanded tourism, international education services, and business mobility. In addition, demands in areas such as cleaner development, stronger intellectual property rights, more robust financial markets and greater certainty and transparency in business law appear.

Also the problem of organizational principles appears for the sake of creation of preconditions for integration and its subsequent strengthening. The following structure of basic principles and principles is offered:

promotion and support of subsequent liberalization of trading in goods and services and investments for the sake of creation of foundation for possible more deep integration in a long-term period;

placing of basic accent on cross-border reforms and forming of business climate for maximization of benefits from cross-border liberalization;

strengthening and deepening of regional financial markets to make it easier to mobilize financial resources;

strengthening of regional economic integration in specific sectors, such as a transport and communications.

It follows to underline that a structure of basic principles, that formed on the base of agreements of FTAs/RTAs, is dynamic, which is provided by the willingness of membercountries to operate within the framework of general interests. And consequently, its components are specific and oriented to the action and can change in the process of collaboration.

Presently, practically all countries of the world continue to do an accent on regional growth and co-operation by introduction of trade and investment liberalization. It is the basic task of countries of the world, which includes measures in the spheres of custom control, standards, intellectual property, transparency, and competition policy rights.

As trade barriers have gradually fallen, burdensome or inconsistent regulatory 
frameworks affecting trade and investment have emerged as significant impediments to business activity and competitiveness.

Consequently the agreements of FTAs/RTAs must not only foresee liberalization of trade and investments, which will promote regional economic integration but also accent attention on reforms which will be directed on internal barriers that hinder trade and slow the economy growing.

The economies of countries of the East-European region have undertaken substantial investment liberalization and reforms in recent years. The FTAs/RTAs agreements can play an important role, in subsequent investment reform in a region.

The key to improving investment climates can become the national strategies in the economies of member-countries which would remove or decrease influence of regulatory barriers to investment. It should be noted that it is not enough to identify the barriers - it is important to provide help in their successive liquidation. It can be attained by joint efforts of member-countries (for example, by the use of experience-sharing) to understand fully the benefits of reform.

Support of structural reforms is one of key moments of strengthening of integration. Directing of these reforms to growth, investment and competitiveness will create positive economic effects for a region.

The proper domestic policy and purposeful policy of structural reforms remain basic for achievement of the higher productivity and global competitiveness. The leadthrough of general structural reforms can create pre-conditions for forming of global competitiveness of region on the whole: however presently structural reforms are specific to every separate economy and depend on the one-sided actions of member-countries.

General reforms can also be politically heavy. However all countries can study from each other and use experience-sharing of their leadthrough. Within the framework of agreements on FTAs/RTAs there is possibility to foresee the grant of help of membercountries to each other by the individual specialized programs developed by a program-target method. The use of this method will give the best results in strengthening of regional economic integration.

This strategic approach must place priority on development of specific recommendations for each of member-countries for promotion of regional economic integration on the whole. Also it must focus actions of member-countries on a long-term prospect and help in their co-ordination.

Necessity of strengthening of financial markets became obvious in the light of financial crisis. Recalibrating and strengthening of collaboration of countries of region in a financial sector is able to create pre-conditions for regional economic integration, economy growth and reformatting of region in obedience to the modern requirements of the globalizing world.

Well-functioning financial sectors are necessary for facilitating investment as they provide markets and intermediaries for matching savings and financing requirements, exercising market discipline and spreading risks.

Underdevelopment of financial sectors in some economies of region, in combination with absence of harmonization and co-ordination of actions in adjusting of financial sectors, create obstacles for entering of internal and external investments to region.

Priorities of reformation of financial sector for the sake of providing of its stability must include strengthening of legal and regulatory frameworks, in particular addressing gaps in property rights, creditor rights and insolvency regimes in some economies; making improvements in disclosure and corporate governance requirements; and also improving physical infrastructure.

Economic integration and providing of the economy growth and reforms is more 
effective if performed on the basis of the use of "sector after a sector" method, oriented on new and the most urgent problems, for example in spheres of energy and resources maintenance, creation of ecologically safe enterprises, transport.

Most effectively this process will take place with close engagement in to the dialog and co-operation of business groups and private sector, which will become the main force of economic integration in a region. As a necessity in regional economic integration increases, it is important to support close connection with the main representatives of business groups.

\section{Remedies}

For the sake of promotion of regional economic integration it is necessary to strengthen work on creation of high-quality, comprehensive agreements of FTAs/RTAs which will open markets and provide economic integration, provide a sequence in agreements and maximize their trade and economic advantages.

In that behalf, offered:

to develop the program of comprehensive and high-quality principles for the generally accepted chapters of FTAs/RTAs agreements and define the ways of their use as guidance for conducting negotiations in relation to FTAs/RTAs;

to conduct the analysis of preferential rules of origin of countries of the region with a purpose of increasing knowledge of their similarities and differences;

explore in close cooperation with the business sector as national systems of the legislative and normative regulation can be rationalized;

to engage in a dialog leading specialists for research of ways of achievement of maximal sequence in key principles of possible agreements of FTAs/RTAs in a region;

to carry out consideration of present bilateral investment agreements, and also general agreements related to the investment with the purpose of creation of principles for the conclusion of general investment agreements.

Within the framework of initiatives from strengthening of business activity by expanding trade and proper investment policy it is necessary to focus trade and investment policy on concrete initiatives which would bolster regional economic integration and decrease the behind-border barriers of countries, including measures what would improve investment climate and competitiveness of economies of countries of region, in particular:

reducing trade transaction costs, due to standardization, unification of custom procedures, electronic commerce and stimulation of business mobility. In particular creation of the unique custom windows is for the countries of region, development of general rules and requirements in relation to confidentiality of information;

creation of the regional system in problems of licensing and patent defense;

association of the infrastructural systems, in particular power systems, for the sake of providing of their efficiency;

encouragement of collaboration with international organizations, for achievement of economic and trade aims of economies of member-countries.

With the purpose of subsequent improvement of investment climate in the economies of the East-European region it is necessary to remove obstacles for investments. It is necessary for the sake of it:

to define and remove internal limits which detain the processes of investing, in addition to measures which are carried out on a border;

to create the unique Investment Assistance Plan of region;

to use diagnostic instruments developed by international organizations;

to extend a dialog on reforms of investment policy of economies of countries 
of region and create the system of experience-sharing on implementation of the proper investment policy;

to conduct work on creation of both state and private enterprises for spreading of investment risks for the sake of increasing of the investment ratings of separate countries and region in a whole.

With the purpose of supporting structural reforms it is necessary to create the proper establishment for co-ordination of actions of countries of region and providing of necessary resources for the leadthrough of structural reforms. It is necessary in that behalf:

to help economies of countries of region on questions of policy of structural reforms and strengthening of local establishments which support the reform process;

to define priority initiatives of reform in the spheres of policy of competitiveness, regulatory reform, strengthening of economic and legislative infrastructure, corporate governance and public sector management with the best potential to improve economic growth and trade;

to conduct works on development of policy of business support, with the use of Ease of Doing Business indicators of the World Bank;

to provide the leadthrough of this policy at the high-level, conducting meeting on structural reform at a ministerial level.

One of key moments of regional economic integration is strengthening of financial markets. It is necessary for the sake of it:

explore possibilities to secure diversified and deeper capital markets;

taking into account transition tendencies in mutual settlements between countries on regional currencies, to create necessary pre-conditions for support of balances of payments of member-countries, in particular, in relation to Ukraine - in Euro and the Russian Rubles;

to direct domestic structural policy and systems which pose barriers on deepening and development of financial markets, sharing of financial information in ways which corresponds the circumstances of certain country of region;

to define possibilities of strengthening of co-operation in the spheres of development of the financial systems and capital markets, create the proper initiative programs, in particular initiatives, for achievement of global standards of financial institutes of countries.

\section{Recapitulation}

One of possible variants of overcoming of financial crisis is the movement toward regional economic integration through the FTAs/RTAs agreements, for the sake of proceeding in economies, economic growth and prosperity through the collective and individual actions of member-countries, developed on the basis of program-target method.

The last years are characterized by the increase of amount of agreements about FTAs/RTAs. By the state on February, 2009 to GATT/WTO about 400 trade agreements were noted.

FTAs/RTAs are the most optimum form of regional integration on the modern stage, which foresee passing to creation and development of free trade, foremost with nearby countries on bi- or multilateral basis.

The FTAs/RTAs agreements solve question which often are not the object of agreements at multilateral level within the WTO framework. These agreements can contain positions on regulation of sphere of competition, investments, intellectual property, services, defense of environment, labor standards.

Taking into account that within the framework of Doha round of negotiations of WTO, 
completion of which was planned yet in 2005 year, it was not succeeded to decide the Singaporean questions at multilateral level, to agree about the general multilateral rules of trade assistance, investment, public purchasing, support of agriculture and competition it follows to expect strengthening of tendency of integration on base of FTAs/RTAs.

Consequently, Ukraine must find the place within the framework of these agreements for the sake of reformation of national economy, leadthrough of structural changes, and increase of competitiveness of country on the whole. Co-operation on bilateral or multilateral basis with the countries of the East-European region and UIC, forming of free trade area with EU are the key aims of participation of our country in integration processes.

\section{REFERENCES:}

1. Shnirkov O. Free trade areas in a world economy // Dzerkalo Tizhnya № 8 (637) 3 - 7 march 2007;

2. Invon Park, Sunchan Park Agreements of free trade versus Customs unions: Review of East Asia, - M, 2008. - 34 p.;

3. Regionalizm: friends or // http://www.wto.org/english/thewto e/whatis e/tif e/bey1 e.htm: quoted by the version of site 15.02.2009;

4. Anthony J.Venables International trade; regional economic integration, - L, 2005. - 16 p.;

5. GATT // http://www.wto.org/english/docs_e/legal_e/gatt47_01_e.htm: quoted by the version of site 14.02.2009;

6. GATS // http://www.wto.org/english/docs_e/legal_e/26-gats_01_e.htm: quoted by the version of site 14.02.2009. 